\title{
analisis Bentuk Perkembangan Wilayah Kecamatan Kartasura Sebagai Kawasan Strategis CePat Tumbuh
}

\author{
ANISAH ${ }^{1}$ \\ PROGRAM STUdi PERENCANAAN WILAYAH DAN KotA \\ FAKULTAS TEKNIK \\ UNIVERSITAS SEBELAS MARET, SURAKARTA \\ email: ANISAH1605@GMAIL.COM \\ SOEDWIWAHJONO ${ }^{2}$ \\ PROGRAM STUdi PERENCANAAN WILAYAH DAN KotA \\ FAKULTAS TEKNIK \\ UNIVERSITAS SEBELAS MARET, SURAKARTA \\ NUR MILADAN ${ }^{3}$ \\ PROGRAM STUDI PERENCANAAN WILAYAH DAN KoTA \\ FAKULTAS TEKNIK \\ UNIVERSITAS SEBELAS MARET, SURAKARTA
}

\begin{abstract}
Regional development based on spatial will form a pattern due to the character that develop in it. The pattern can be formed by the network, hierarchy, and so forth. The influence of policies that encourage development to bring new activities in the region is also capable of bringing changes. As a rapidly growth strategic area established by the district government, Kartasura District has variety of new activities. This research is used to know how the development on regional form of Kartasura District as a rapidly growth strategic area. It uses longitudinal development method with analytical approach used is deductive and quantitative descriptive research type. The compilation and analysis techniques used are primary data collection (observation) also secondary; Descriptive statistics, GIS and overlay, breaking point. The result of this research are the development of Kartasura sub-district as rapidly growth strategic area which is formed pattern based on the network also the limitation of development as a result of supporting policy causing the difference internal development on Kartasura District.
\end{abstract}

Keywords: Regional Development, Region Form, Regional Development Pattern, GIS, Spatial

\section{PENDAHULUAN}

Indonesia saat ini memiliki kebijakan pemerataan pertumbuhan dan perkembangan wilayah yang secara umum disebut kawasan strategis yang dibagi menjadi beberapa kepentingan yaitu pendayagunaan sumber daya dan teknologi, ekonomi, sosial budaya, pertahanan dan keamanan, serta fungsi dan daya dukung lingkungan hidup. Dalam kawasan strategis ekonomi, kawasan yang diperuntukkan untuk meningkatkan pertumbuhan wilayah diwujudkan salah satunya dalam bentuk kawasan strategis cepat tumbuh (KSCT).

Kecamatan Kartasura sebagai Pusat Kegiatan Lokal (PKL) dalam Rencana Tata Ruang Wilayah (RTRW) Kabupaten Sukoharjo tahun 2011-2031, ditetapkan sebagai kawasan strategis untuk beberapa kepentingan kabupetan yang secara operasional salah satunya adalah Kawasan Strategis Cepat Tumbuh, selain Kecamatan Grogol dan Sukoharjo. Terdapat arahan kawasan peruntukan 
industri yang mampu menjadi penggerak tumbuhnya aktivitas lain pada Kecamatan Kartasura yang menyebabkan terjadinya perubahan perkembangan wilayah.

Namun, dalam Buku Akhir Rencana Detail Tata Ruang Kecamatan Kartasura Tahun 2014-2034 disebutkan bahwa perkembangan aktivitas perkotaan Kecamatan Kartasura mengarah ke timur (menuju Kota Surakarta) serta ke arah utara menuju (Kecamatan Colomadu). Hal tersebut dikarenakan munculnya kebijakan yang kurang mendukung terwujudnya pembangunan sebagai KSCT di Kecamatan Kartasura. Perlu dianalisis lebih lanjut bagaimana perkembangan bentuk wilayah Kecamatan Kartasura setelah ditetapkan sebagai KSCT mampu menjawab isu ketidakmerataan perkembangan perkotaan Kecamatan Kartasura.

\section{TINJAUAN PUSTAKA \\ 2.1 Wilayah}

Wilayah merupakan kesatuan alam yaitu alam yang homogen dan kesatuan manusia yaitu masyarakat serta kebudayaannya yang sama yang memiliki ciri khas, sehingga wilayah tersebut dapat dibedakan dengan daerah lainnya (J.T. Jayadinata, 1999). Sedangkan makna lain dari wilayah adalah yang secara geografis bersatu dengan adanya kesamaan budaya, perekonomian, hingga kemudian dengan konsensus kesamaan pemikiran, pendidikan, rekreasi dan lainnya yang membedakan dengan wilayah lainnya (K.Young dalam J.T.Jayadinata, 1999).

Lebih lanjut, terdapat empat 112 si dalam penentuan wilayah. ..... rertama biasa disebut sebagai wilayah fungsional. Menurut J.T.Jayadinata, wilayah fungsional merupakan sebuah bagian dari permukaan bumi yang memungkinkan timbulnya berbagai kegiatan, dan hasilnya pun berbeda-beda sehingga menimbulkan keterkaitan dan ketergantungan (saling mengisi) guna melengkapi kehidupan penduduk di dalamnya. Kedua merupakan wilayah formal/homogen yang didasarkan pada kesamaan kriteria tertentu dalam suatu kriteria dan merupakan sesuatu yang mudah dilihat seperti aspek fisik (Jarwoto,2007). Ketiga adalah wilayah perencanaan yang merupakan kombinasi dari tipe wilayah fungsional dan formal. Boudeville dalam Glasson dalam Setyono (2007) mengartikan wilayah perencanaan sebagai kawasan yang ditetapkan karena adanya keputusan-keputusan ekonomi. Keempat merupakan wilayah administratif yang memiliki makna wilayah yang batas-batasnya di tentukan berdasarkan kepentingan administrasi pemerintahan atau politik, seperti: propinsi, kabupaten, kecamatan, desa/kelurahan, dan RT/RW. Sukirno dalam Emilia Imelia (2006) menyatakan bahwa di dalam praktek, apabila membahas mengenai pembangunan wilayah ,maka pengertian wilayah administrasi merupakan pengertian yang paling banyak digunakan.

\subsection{Perkembangan Wilayah}

Perkembangan merupakan hasil dari proses pembentukan yang dipengaruhi oleh faktor-faktor tertentu. Sedangkan pengembangan merupakan inovasi/proses yang dilakukan guna mencapai tujuan.

Bertambahnya aktivitas baik dari segi ekonomi maupun sosial mengakibatkan adanya perkembangan atau transformasi yang membentuk geografi wilayahnya, yang biasa disebut sebagai perkembangan wilayah. Pembentukan wilayah ini bisa terjadi karena beberapa faktor diantaranya jalan, fungsional, spesialisasi dan lain sebagainya. Di bawah ini merupakan 
bentuk dan model perkembangan wilayah:

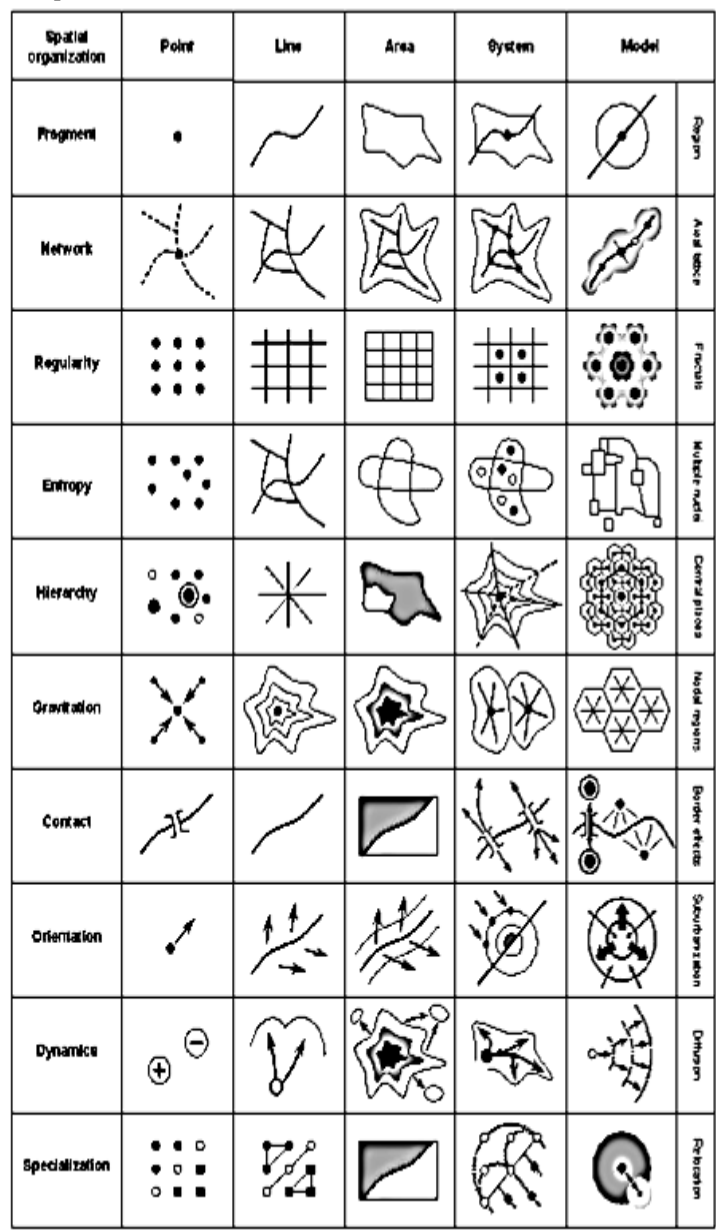

Gambar 1. Model Perkembangan Bentuk Wilayah (Klapka, Pavel,et.al, 2010)

Perbedaan perkembangan kondisi hasil pembangunan menimbulkan perbandingan antar wilayah dan informasi yang disebut gap (kesenjangan) antara daerah yang maju dan tertinggal. Menurut Alonso dalam Setyono (2007), untuk mengetahui perkembangan dalam suatu wilayah terdapat tahapan perkembangan, yaitu adanya perkembangan dalam hal ekonomi dan keruangan. Sedangkan menurut Rostow (Gore dalam Setyono, 2007) tahapan perkembangan wilayah dimulai dari : 1) tradisional, masih terbatasnya teknologi serta kuatnya perbedaan strata dimata masyarakat; 2) prakondisi tinggal landas, mulai munculnya keseimbangan dengan adanya investasi dari wilayah maju terhadap wilayah yang tertinggal; 3) tinggal landas, adanya efek penggandaan (multiplier effect); 4) kematangan, kegiatan industri mulai stabil dan perekonomian mulai sesuai harapan; 5) konsumsi massa, wilayah mampu melakukan ekspor barang dan jasa; Ketimpangan Sosial (Social Inequality); Ketimpangan Wilayah (Regional Inequality); Konsentrasi Geografis (Geographic Concentration); Transisi Demografi (Demographic Transition)

Friedmann dalam Erwin Harahap (2009) menyatakan bahwa perkembangan wilayah dipengaruhi oleh pusat pertumbuhan dan struktur wilayah. Dalam Kocziszky (2009) disebutkan bahwa untuk mengetahui perkembangan wilayah, hal-hal yang perlu dilihat adalah potensi sumberdaya alam, demografi, kondisi sosial, kondisi ekonomi, infrastruktur, dan struktur keruangan.

\section{METODE PENELITIAN}

Penelitian ini disusun berdasarkan dua pendekatan KSCT berdasarkan perkembangan wilayah berbasis spasial. Pendekatan ini dimaksudkan untuk mengetahui perkembangan wilayah secara terbangun dan penataan ruangnya. Hambatan serta potensi dapat diketahui dengan variabel yaitu struktur pusat pertumbuhan (perubahan penggunaan lahan pada wilayah sehingga muncul pusat-pusat pertumbuhan yang masing-masing memiliki hubungan erat berdasarkan interaksi yang dilakukan)

Pengumpulan data dilakukar observasi untuk mengetahui gu $\quad 113$ eksisting dengan peta borang sebagai alat observasi. Dengan observasi ini mampu diketahui perubahan aktivitas yang terjadi maupun munculnya aktivitas baru di Kecamatan Kartasura. Selain itu juga dilakukan pengumpulan data sekunder sebagai pendukung 
analisis yang merupakan analisis perkembangan dari tahun $2011-2016$.

Teknik analisis yang digunakan terdiri atas 3 teknik yang masing-masing penjelasannya sebagai berikut:

- Analisis statistik deskriptif : Statistik di sini diolah secara kuantitatif baru kemudian dideskripsikar 113 disimpulkan. Data yang dicaiı auaran data luasan konsentrasi guna lahan dan jumlah penduduk.

- Analisis GIS (Pemetaan dan overlay): Pemetaan dipergunakan untuk menggabungkan data, mengatur data dan melakukan analisis data yang akhirnya akan menghasilkan keluaran yang dapat dijadikan acuan dalam pengambilan keputusan pada masalah yang berhubungan dengan geografi. Sedangkan pada overlay merupakan penggabungan keseluruhan analisis sehingga dapat diketahui perkembangannya baik dari tingkat maupun pola. Penelitian ini menggunakan teknik pemetaan pada analisis konsentrasi guna lahan serta interaksi antar pusat. Sedangkan untuk overlay digunakan mengetahui perkembangan wilayah Kecamatan Kartasura sebagai KSCT.

- Analisis Breaking Point

Analisis breaking point digunakan untuk menentukan lokasi paling optimal dalam pencapaian dan pengaruhnya. Penelitian ini menganalisis seberapa besar pengaruh KSCT terhadap wilayah sekitarnya.

\section{ANALISIS DAN PEIMBAHASAN} 114

rerkemoangan penggunaan lahan Kecamatan Kartasura pada tahun 2011 hingga tahun 2015 tidak mengalami perubahan yang besar. Namun, pada tahun 2016 mulai terjadi pembangunan perumahan maupun apartemen di Kecamatan Kartasura (pembangunannya tidak terjadi alihfungsi lahan pada seluruh ruang terbuka di Kecamatan Kartasura). Perumahan yang dibangun merupakan alih fungsi lahan dari sawah sedangkan untuk apartemen dibangun dari bangunan yang sudah tidak terpakai. Selain itu, terjadi pula peningkatan perdagangan jasa di Kecamatan Kartasura mulai dari tahun 2011 hingga 2016, yang mana tumbuhnya mengikuti jalan utama. 


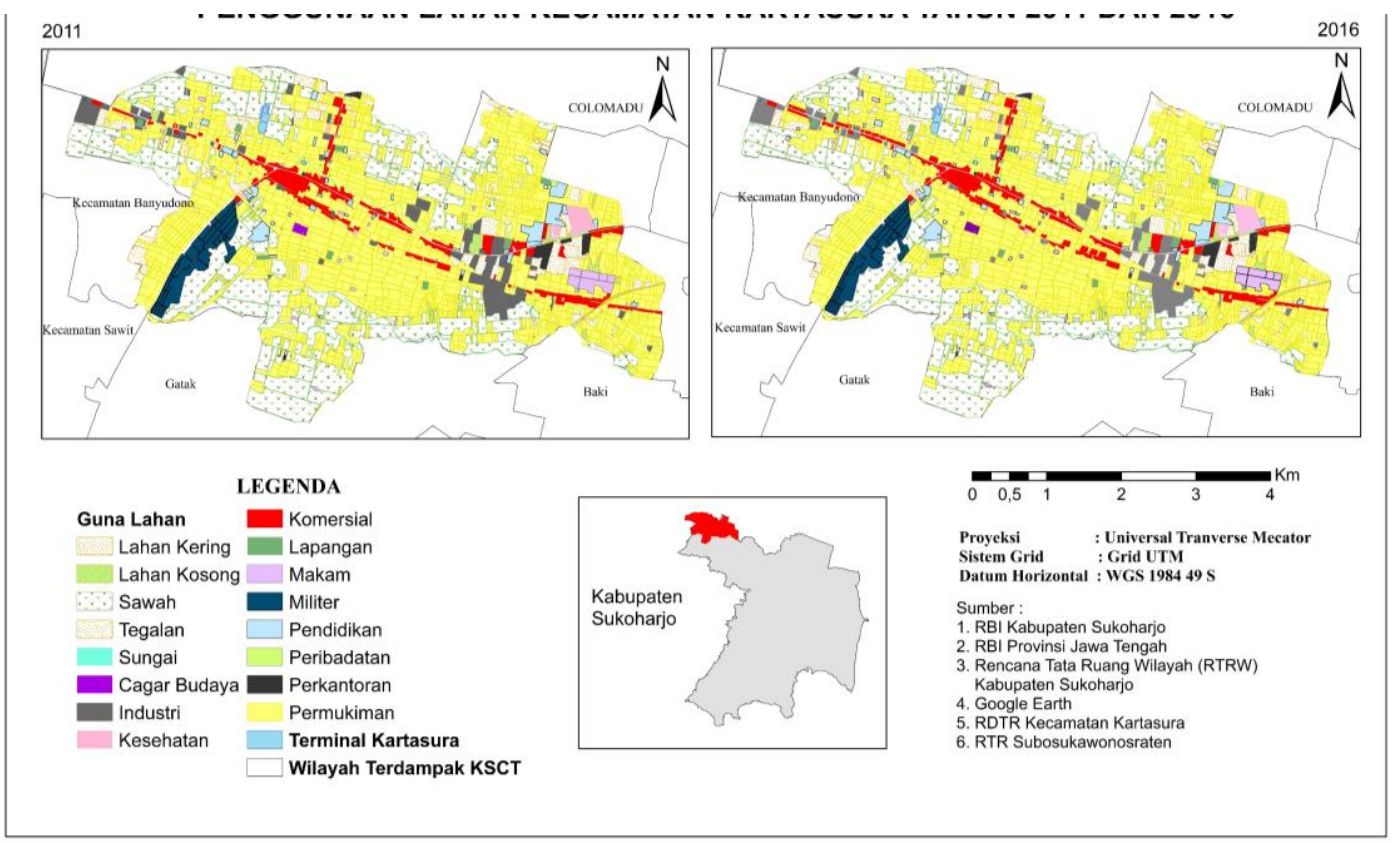

Gambar 2. Peta Penggunaan Lahan Kecamatan Kartasura Tahun 2011 dan 2016 ( Analisis Peneliti, 2017)

Berdasarkan peta penggunaan lahan dari tahun 2011 hingga 2016 tersebut, dapat disimpulkan bahwa pembangunan dan alih fungsi lahan di Kecamatan Kartasura tidak terlalu signifikan. Arah pembangunannya merupakan limpasan dari pembangunan di Kota Surakarta (dari arah timur Kecamatan Kartasura, seperti yang dijelaskan pada RDTR Kecamatan Kartasura), sedangkan mengarah ke utara menuju Kecamatan Colomadu yang juga merupakan KSCT dari Kabupaten Karanganyar. Pembangunan secara fisik belum terlalu terlihat pada arah selatan dan barat Kecamatan Kartasura, hanya saja mulai berkembangnya

penggunaan perkantoran, industri, dan perdagangan jasa pada wilayah ini.

Dari peta tersebut juga dapat dilihat bahwa pembangunan terkonsentrasi pada Kecamatan Kartasura, Ngadirejo, Desa Pabelan, Makamhaji, Gonilan, Singopuran, dan Ngabeyan. Sedangkan sisanya belum terlihat pembangunan

Region, Vol. 12, No. 2, Juli 2017

bahwa bagian barat dan selatán
Kecamatan Kartasura diprioritaskan untuk memenuhi program ketahanan pangan nasional, sehingga dengan sekitar 110,34 Ha ditetapkan sebagai sawah lestari yang direncanakan pada Desa Wirogunan, Pucangan, Gumpang, dan Ngemplak. Karena konsep KSCT yang ditujukan untuk pemerataan pembangunan dan konsentrasi penggunaan lahan, maka perencanan ini dianggap menyalahi tujuan KSCT sendiri.

Perbedaan guna lahan yang mencolok, yaitu pembangunan fisik pada bagian timur dan utara dan penetapan wilayah lestari pada bagian barat dan selatan, akan menyebabkan kesenjangan wilayah Kecamatan Kartasura.

\section{Breaking Point}

Analisis ini dimaksudkan untuk mengetahui apakah Kecamatan Kartasura sebagai KSCT mempengaruhi wilayah sekitarnya atau sebaliknya. Pengaruh tersebut didapatkan dari nilai wilayah yang lebih besar sebagai daerah yang ıgaruhi, dalam penelitian ini an indikator penduduk dalam perhitungannya.

Tabel 1. Hasil Analisis Pengaruh dan Interaksi KSCT Terhadap Daerah Sekitar

\begin{tabular}{l|l|l} 
Wilayah Interaksi & Tahun & Keterangan
\end{tabular}


Region, Vol. 12, No. 2, Juli 2017: 111-118

\begin{tabular}{|c|c|c|c|c|c|c|}
\hline & 2011 & 2012 & 2013 & 2014 & 2015 & \\
\hline Kartasura-Banyudono & 3,80 & 3,78 & 3,76 & 3,75 & 3,90 & \multirow{6}{*}{$\begin{array}{l}\text { Dengan range nilai }: \\
\text { Tinggi }=>3,24 \\
\text { Sedang }=2,58-3,24 \\
\text { Rendah }=1,91-2,57\end{array}$} \\
\hline Kartasura-Sawit & 3,39 & 3,36 & 3,35 & 3,33 & 3,17 & \\
\hline Kartasura-Colomadu & 1,91 & 2,03 & 2,03 & 2,02 & 2,05 & \\
\hline Kartasura-Gatak & 2,86 & 2,86 & 2,86 & 2,86 & 2,86 & \\
\hline Kartasura-Baki & 3,83 & 3,83 & 3,84 & 3,84 & 3,83 & \\
\hline Kartasura-Laweyan & 3,31 & 3,35 & 3,35 & 3,36 & 3,38 & \\
\hline
\end{tabular}

Sumber : Analisis Peneliti, 2017

Berdasarkan hasil analisis tersebut, Kecamatan Kartasura memiliki pengaruh yang tinggi terhadap perkembangan Kecamatan Baki, Banyudono, dan Sawit. Pengaruh ini dimaksudkan dalam perkembangan baik dari segi permukiman hingga perekonomian yang mana salah satu contohnya adalah tarikan pekerja terhadap sarana yang ada di Kecamatan Kartasura.

Untuk Kecamatan Gatak pengaruh yang diberikan sebagai KSCT terbilang sama dengan timbal balik dari Kecamatan Gatak. Sedangkan untuk Kecamatan Colomadu pengaruh yang diberikan Kecamatan Kartasura terbilang rendah, hal ini dimungkinkan karena merupakan KSCT pada Kabupaten Karanganyar sehingga memiliki kemandirian dalam perkembangan wilayahnya.

Berbeda dengan Kecamatan lainnya, Kecamatan Laweyan merupakan wilayah yang justru mempengaruhi perkembangan wilayah di Kecamatan Kartasura. Dijelaskan dalam Rencana Detail Tata Ruang Kecamatan Kartasura tahun 2014-2034, pengaruh ini dapat dikatakan sebagai limpasan karena mulai tidak tertampungnya permukiman di Kecamatan Laweyan (Kota Surakarta) juga daya tarik perkerjaan yang mana masyarakat Kecamatan Kartasura banyak bekerja di Laweyan. Untuk itu, dapat disimpulkan bahwa Kecamatan Kartasura sebagai KSCT sudah mampu memberikan pengaruh terhadap wilayah sekitarnya, namun kurang mampu mempengaruhi Kecamatan Colomadu yang juga merupakan KSCT dan tetap mendapatkan pengaruh dari wilayah yang lebih besar berdasarkan hierarkinya yaitu Kecamatan Laweyan (Kota Surakarta).

Berdasarkan analisis di atas, kemudian dapat dihasilkan simpulan mengenai perkembangan wilayah Kecamatan Kartasura yang terjadi dalam perubahan bentuk wilayahnya yaitu adanya limpasan dari Kota Surakarta yang kemudian mendesak pusat perkotaannya dan mengembangkan wilayahnya secara ekstensifikasi menuju utara (arah Kecamatan Colomadu).

Peta arah perkembangan wilayah Kecamatan Kartasura dapat dilihat pada gambar 2. Berdasarkan peta tersebut, terlihat bahwa bentuk wilayah yang berkembang di Kecamatan Kartasura adalah bentuk networking yaitu perkembangan wilayah yang didasarkan atas aksesibilitas yang terbentuk. Aksesibilitas ini juga terbentuk karena pengaruh besar dari limpasan Kota Surakarta yang menyebabkan Kecamatan Kartasura membuka akses baru untuk memenuhi kebutuhan permukiman penduduk. Penetapan kebijakan sawah lestari yang hanya diarahkan pada bagian barat dan selatan menyebabkan perkembangan wilayah condong ke arah utara, hal ini dikhawatirkan sebagai penyebab kesenjangan perkembangan di Kecamatan Kartasura sebagai KSCT. 


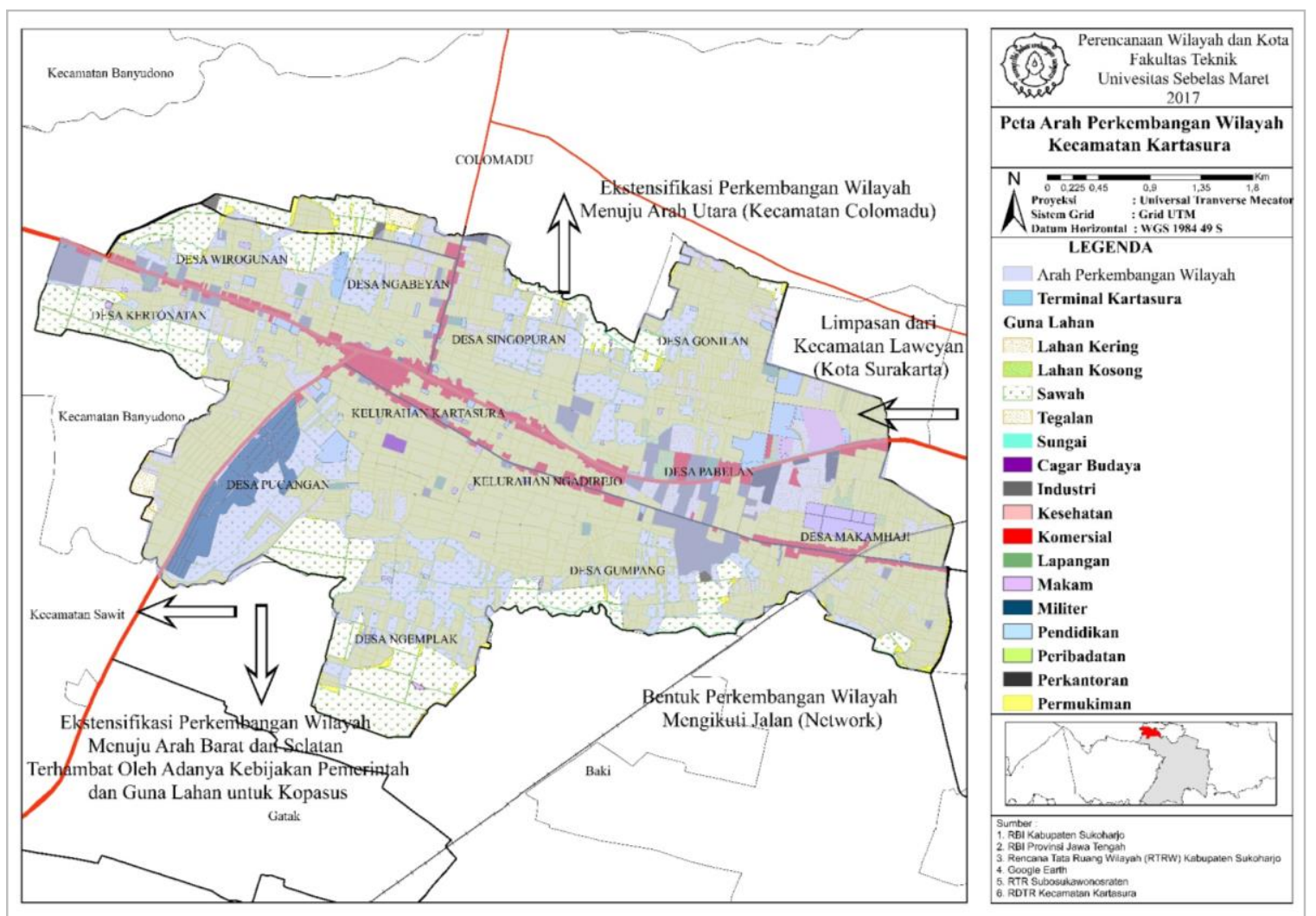

Gambar 3. Peta Arah Bentuk Perkembangan Wilayah Kecamatan Kartasura ( Analisis Peneliti, 2017)

\section{KESIMPULAN}

Perkembangan wilayah internal Kecamatan Kartasura belum mampu menjawab isu ketimpangan wilayahnya. Hal ini dikarenakan kebijakan sebagai KSCT belum didukung dengan kebijakan-kebijakan yang mampu meratakan pembangunan sehingga bentuk wilayah yang terbentuk tidak kompak. Pola yang terjadi mengikuti jaringan jalan atau biasa disebut dengan netowork. Jaringan jalan yang ada juga merupakan hasil dari aktivitas yang muncul sebagai perkembangan pembangunan.

Perkembangan spasial yang terjadi di Kecamatan Kartasura masih tergolong rendah. Hal ini dikarenakan laju pertumbuhan dan sebaran penduduk juga penggunaan lahannya dengan kepadatan tinggi hanya terkonsentrasi pada pusat pertumbuhan (desa/kelurahan) tertentu.
Pengaruh perkembangan wilayahnya terhadap sekitar sudah tergolong tinggi, kecuali untuk Kecamatan Laweyan yang memiliki hierarki lebih tinggi juga merupakan wilayah yang mempengaruhi perkembangan wilayah Kecamatan Kartasura.

\section{REFERENSI}

Harahap, Erwin. 2009. Thesis: Kecamatan Perbaungan Sebagai Pusat Pertumbuhan di Kabupaten Serdang Bedagai. Medan Universitas Sumatera Utara

Imelia dan Emilia. 2006. Modul: Ekonomi Regional. Jambi: Universitas Jambi Jayadinata, T.Johara. 1999. Tata Guna Tanah Dalam Perencanaan Pedesaan Perkotaan. Bandung : Penerbit ITB

Klapka, Pavel, dkk. 2010. Spatial Organisation : Development, Structure, 
And Approximation Of Geographical Systems . Czech Republic : Moravian Geographical Report

Kocziszky, György. 2009. Methodology of Regional Development (Almée Réti, Penerjemah). Miskolc : The University of Miskolc Press

Setyono, S. Jawoto. 2007. Pengantar Perencanaan Wilayah dan Kota. Semarang: Universitas Diponegoro

Peraturan Daerah Kabupaten Sukoharjo Nomor 14 Tahun 2011. Rencana Tata Ruang Wilayah Kabupaten Sukoharjo tahun 2011-2031. Sukoharjo 